УДК 681.586

\author{
B. В. Туз , к.т.н.. доиент, \\ e-mail: clava2005@gmail.com \\ Т. Ю. Кісіль, к.т.н.. доиент \\ e-mail: kisiltetyana@ukr.net \\ Черкаський державний технологічний університет \\ б-р Шевченка, 460, м. Черкаси, 18000, Україна,
}

\title{
ДОСЛІДЖЕННЯ ТА ВИБІР ОПТИМАЛЬНОЇ СХЕМОТЕХНІЧНОЇ МОДЕЛІ БІМОРФНОГО П'ЄЗОЕЛЕМЕНТА ДИНАМІЧНИХ ТИСКІВ 3 ДВОКОНТУРОВИМ ВІД'ЄМНИМ ЗВОРОТНИМ ЗВ'ЯЗКОМ
}

Розглянуто питання щзодо вибору оптимальної схемотехнічної моделі біморфного п'єзоелемента динамічних тисків з двоконтуровим від'ємним зворотним зв'язком та досліджено характеристики п'єзоперетворювачів з вихідним підсилювачем заряду та підсилювачем напруги в додатковому каналі зворотного зв'язку.

Ключові слова: біморфний п'єзоелемент, n'єзоперетворювач, від'ємний зворотний зв'язок, температурні параметри, часові параметри, підсилювач заряду, підсилювач напруги.

Постановка проблеми. Як відомо, від характеристик перетворювачів значною мірою залежать точність і надійність роботи систем керування та регулювання, приладів контролю технологічних процесів, навколишнього середовища, безпеки роботи морських об'єктів, тому роботи по створенню нових та вдосконаленню відомих перетворювачів $є$ досить актуальними.

В гідро- та електроакустиці, вимірювальній техніці й інших галузях контролю та вимірювання багатьох фізичних величин сили, динамічного і статичного тиску, густини та інших величин - широке застосування знайшли п'єзоперетворювачі. Вони мають високу чутливість, малі габарити і масу, високу завадостійкість, малий рівень власних шумів, підвищену радіаційну стійкість.

Досягнуто значних результатів у цій галузі, внаслідок чого було розроблено велику кількість перетворювачів. Однак головним їх недоліком є обмежений робочий діапазон частот перетворювачів, зумовлений малою резонансною частотою п'єзоелемента.

Тому роботи по вдосконаленню поліморфних, у тому числі й найбільш поширених біморфних, п'єзоперетворювачів динамічних тисків для отримання нових властивостей, розширення робочого діапазону частот, а також підвищення стабільності температурних і часових параметрів п'єзоперетворювачів систем управління $€$ актуальними.

Аналіз джерел досліджень і публікацій. При введенні зворотного зв'язку елект- ричні сигнали вводяться і знімаються з п'єзоелемента за допомогою металевих електродів, розташованих на поверхні перетворювача. Однак через обмежені розміри електродів електричний сигнал зворотного зв'язку не може впливати на весь об'єм п'єзоелемента. Це знижує ефект від введення зворотного зв'язку і не дозволяє в ряді випадків досягти потрібних результатів. Таким чином, на практиці виконання умов рівності нулю похибки виміру $(\gamma=0) є$ важкодосяжним [1].

Для компенсації зазначеної недостатності раніше було запропоновано використовувати метод структурно-енергозберігаючої трансформації з двоконтурним простим електромеханічним негативним зворотним зв'язком (ПЕСС) [2-5].

Як узгоджувальні підсилювачі в ланцюгах зворотних зв'язків у п'єзоперетворювачах можуть використовуватися як підсилювачі заряду, так і підсилювачі напруги, 3 виходу яких знімається корисний сигнал.

Нині 3 п'єзоелектричними датчиками застосовуються так звані підсилювачі заряду. Вони повністю виключають вплив довжин зв'язних кабелів на загальну чутливість відповідних комплектів і систем i, отже, допускають застосування зв'язних кабелів практично будь-якого розміру.

В роботах Шарапова В. М. [5, 6] i Мусієнка М. П. [1] розглянуто п'єзоперетворювачі з двоконтурним зворотним зв'язком, де як основний (вихідний) підсилювач засто- 
совується напруга підсилювача, а в каналі додаткового зворотного зв'язку - підсилювачі напруги та заряду. У цих роботах не розглянуто перетворювачі, де як основний підсилювач виступає підсилювач заряду, а додатковий - напруги. Крім того, дослідження проводилися тільки для мономорфних п'єзоелементів, що також $є$ лише окремим випадком великого класу п'єзоперетворювачів.

Мета роботи - вибір оптимальної схемотехнічної моделі біморфного п'єзоелемента динамічних тисків 3 двоконтуровим від'ємним зворотним зв'язком і дослідження п'єзоперетворювачів 3 вихідним підсилювачем заряду та підсилювачем напруги в додатковому каналі зворотного зв'язку.

Постановка задачі. П'єзоелемент поляризовано так, як це зображено на рис. 1. Електроди на відповідних гранях розділені на дві частини, утворюючи чотири пари електродів. Для чотирьох пар електродів (1-1/, 2-2/, 3-3/, 4-4/) вектор поляризації Р направлений перпендикулярно цим електродам.

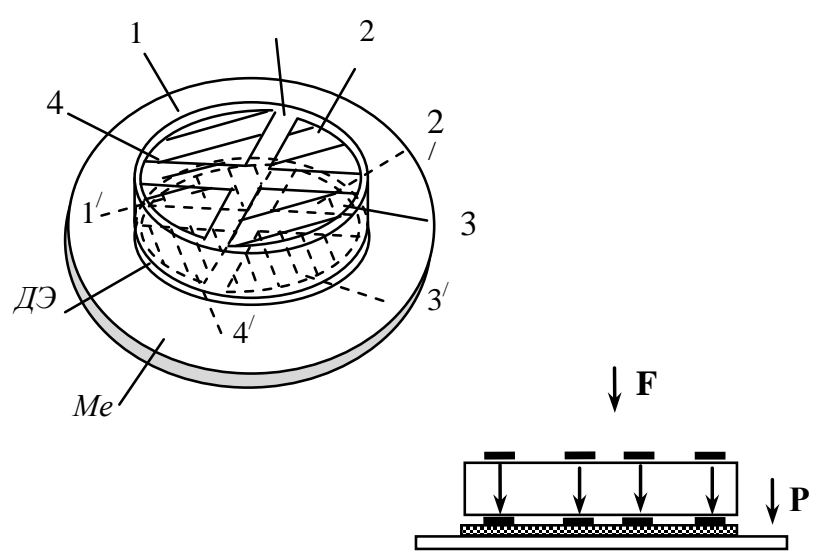

Рис. 1. Біморфний п'єзоэлемент:

1-1', 2-2', 3-3/, 4-4' - електроди

Підключення до такого електрода будемо позначати на схемах перетворювачів вертикальною стрілкою $(\downarrow)$. Такий перетворювач $\epsilon$ традиційним і буде мати властивості вібраційних систем $[2,5,7]$. Всі можливі варіанти перетворювачів наведено в табл. 1. У варіантах перетворювачів № 1-9 вектор сили F, що прикладається, паралельний вектору поляризації Р.
Таблиця 1

\section{Можливі варіанти перетворювачів}

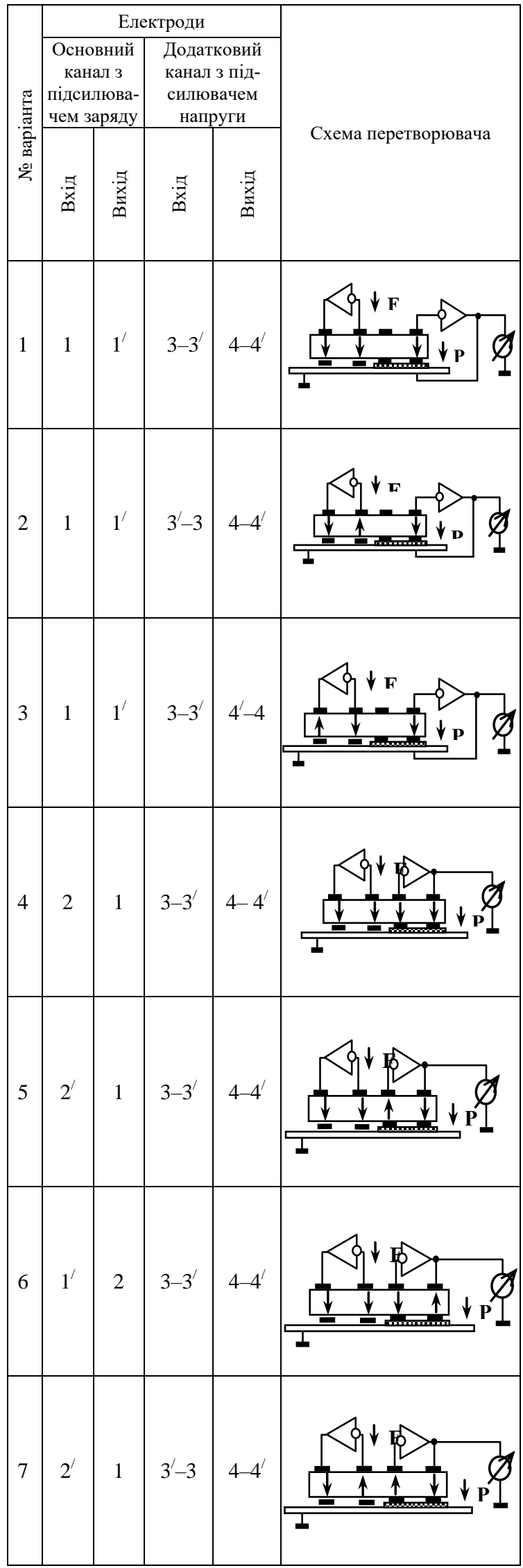




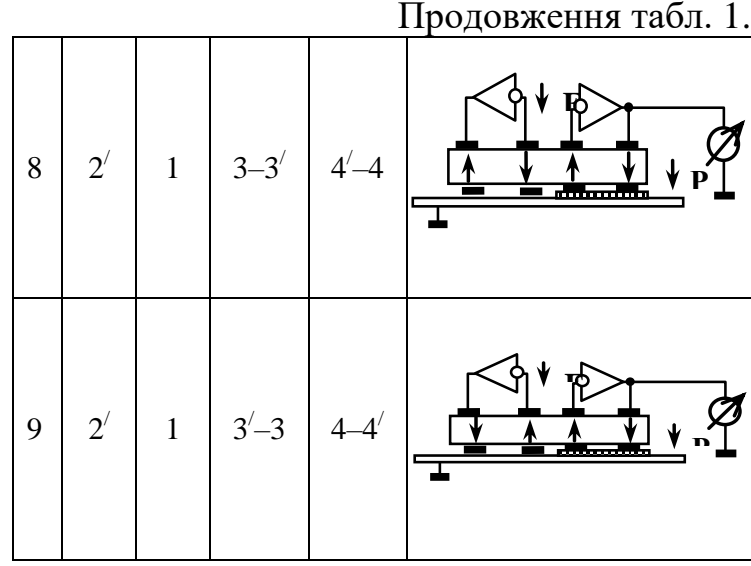

Структурну схему перетворювача зображено на рис. 2.

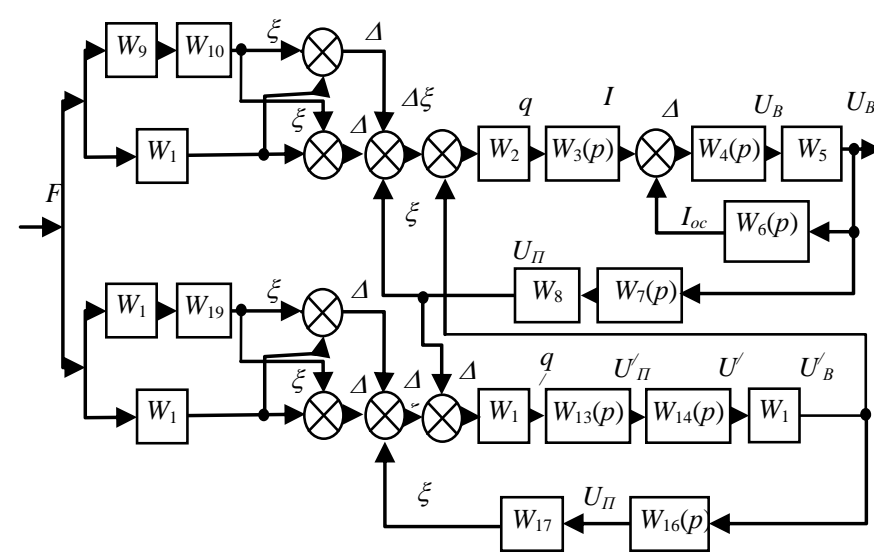

Рис. 2. Структурна схема п'єзоперетворювачів 3 двоконтуровим зворотним зв'язком с вихідним підсилювачем заряду і підсилювачем напруги в додатковому каналі зворотного зв'язку

$\mathrm{W}_{1}, \mathrm{~W}_{11}, \mathrm{~W}_{9}, \mathrm{~W}_{19}, \mathrm{~W}_{18}$ і $\mathrm{W}_{10}$ - коефіцієнти передачі ланок, що відповідають перетворенню сили F, яка діє на п'єзоелемент, в деформацію п'єзоелемента; $\mathrm{W}_{2}$ i $\mathrm{W}_{12}$ - перетворення $\xi$ в заряд q на електродах п'єзоелемента; $\mathrm{W}_{3}(\mathrm{p})$ - перетворення заряду q в ток Iq, який створює п'єзоелемент; $\mathrm{W}_{4}(\mathrm{p})$ - перетворення сумарного струму у вхідну напругу, що надходить на вхід підсилювача заряду $\mathrm{U}_{\mathrm{BX}} ; \mathrm{W}_{5}$ - посилення підсилювача заряду; $\mathrm{W}_{6}(\mathrm{p})$ - перетворення вихідної напруги підсилювача $U_{\text {вих }}$ в струм зворотного зв'язку Із3, що проходить через конденсатор зворотного зв'язку (33) операційного підсилювача; $\mathrm{W}_{7}(\mathrm{p})$ i $\mathrm{W}_{16}(\mathrm{p})$ передача вихідної напруги підсилювача $\mathrm{U}_{\text {вих }}$ в напругу між електродами п'єзоелемента $\mathrm{U}_{\text {пЕ }}$; $\mathrm{W}_{8} \mathrm{i}_{17}$ - перетворення $\mathrm{U}_{\text {ПЕ }}$ в деформацію п'єзоелемента; $\mathrm{W}_{13}(\mathrm{p})$ - перетворення $\mathrm{q}^{\prime}$ в напругу на електродах п'єзоелемента $\mathrm{U}^{\prime} \Pi_{1}$; $\mathrm{W}_{14}(\mathrm{p})$ - перетворення $\mathrm{U}^{\prime} \Pi_{1}$ в напругу на вході підсилювача напруги; $\mathrm{W}_{15}$ - посилення підсилювача напруги.

Передавальна функція має вигляд:

$$
\begin{aligned}
W o c(p)= & \frac{2 \cdot W_{2} \cdot W_{3}(p) \cdot W_{4}(p) \cdot W_{5} \times}{1+W_{12} \cdot W_{13}(p) \cdot W_{14}(p) \cdot W_{15} \cdot W_{16}(p) \cdot W_{17}+W_{4}(p) \cdot W_{5} \times} \\
& \frac{\times\left[\left[W_{1}-W_{9} \cdot W_{10}\right] \cdot\left[1+W_{12} \cdot W_{13}(p) \cdot W_{14}(p) \cdot W_{15} \cdot W_{16}(p) \cdot W_{17}\right]+\right.}{\times\left[W_{6}(p) \cdot\left[1+W_{12} \cdot W_{13}(p) \cdot W_{14}(p) \cdot W_{15} \cdot W_{16}(p) \cdot W_{17}\right]+\right.} \\
& \frac{\left.+W_{12} \cdot W_{13}(p) \cdot W_{14}(p) \cdot W_{15} \cdot\left[W_{18} \cdot W_{19}-W_{11}\right]\right]}{+W_{2} \cdot W_{3}(p) \cdot W_{8} \cdot W_{7}(p) \times} \\
& \frac{\left.\times\left[1+W_{12} \cdot W_{13}(p) \cdot W_{14}(p) \cdot W_{15} \cdot\left[W_{16}(p) \cdot W_{17}-1\right]\right]\right]}{}
\end{aligned}
$$

Ланка 3 коефіцієнтом передачі $\mathrm{W}_{1}$ відповідає перетворенню сили $\mathrm{F}$, що діє на п'єзоелемент, в механічне напруження $\sigma$; де $\mathrm{F}_{\mathrm{m}}$ - діюча сила, $\mathrm{m}$ - маса п'єзоелемента, $\Delta$ - коефіцієнт згасання системи, $\mathrm{F}_{\mathrm{p}}$ - частота власного резонансу, $\mathrm{f}$ - частота $[1,7,8]$.

Тоді,

$$
W_{1}=\frac{F m}{\sqrt{m^{2} \cdot\left(F p^{2}-f\right)^{2}+(2 \cdot m \cdot \Delta)^{2} \cdot f^{2}}}
$$

Ланка $\mathrm{W}_{2}$ відповідає перетворенню механічної напруги в заряд q на електродах п'єзоелемента. Оскільки $q=d_{i j} \Delta \sigma S$, то

$$
W_{2}=q / \Delta \sigma=d_{\mathrm{ij}} S,
$$

де dij - п'єзомодуль.

Ланка $\mathrm{W}_{3}(\mathrm{p})$ - перетворення заряду q в струм Iq, який створює п'єзоелемент:

$$
I_{q}=\frac{d q}{d t}
$$

Тоді, з урахуванням переходу в Лапласовий простір, отримаємо:

$$
W_{3}(p)=\frac{I_{q}}{q}=p
$$

де $\mathrm{p}$ - оператор Лапласа.

Ланка $\mathrm{W}_{4}(\mathrm{p})$ відповідає перетворенню сумарного струму у вхідну напругу, що надходить на вхід підсилювача $\mathrm{U}_{\mathrm{BX}}$ :

$$
U_{B X}=\frac{1}{C_{\Sigma}} \int I_{q} d t
$$

де $C_{\Sigma}=C_{\Pi \ni}+C_{K}+C_{B X}, C_{\Pi \ni}-$ ємність п'єзоелемента, $\mathrm{C}_{K}-$ ємність з'єднувального кабелю і відповідних з'єднувачів, $\mathrm{C}_{B X}-$ ємність вхідного ланцюга підсилювача заряду.

Передавальна функція ланки $\mathrm{W}_{4}(\mathrm{p})$ має вигляд:

$$
W_{4}(p)=\frac{U_{B X}}{I_{q}}=\frac{1}{C_{\Sigma} \cdot p}
$$

Ланка $\mathrm{W}_{5}$ відповідає процесу посилення підсилювача заряду:

$$
W_{5}=K_{\text {Y3 }}
$$


Ланка $\mathrm{W}_{6}(\mathrm{p})$ відповідає перетворенню вихідної напруги підсилювача $\mathrm{U}_{\text {вих }}$ в струм зворотного зв'язку $\mathrm{I}_{\mathrm{OC}}$, що проходить через конденсатор зворотного зв'язку операційного підсилювача

$$
U_{B b I X}=\frac{I}{C_{\Sigma}{ }^{\prime}} \cdot \int I_{O C} d t
$$

де $\mathrm{C}_{\Sigma}=$ Сз3+Свих, Сзз - ємність конденсатора в колі зворотного зв'язку операційного підсилювача, $\mathrm{C}_{\text {вих }}$ - ємність вихідного ланцюга підсилювача.

Після перетворення отримаємо:

$$
W_{6}(p)=\frac{I_{O C}}{U_{B D I X}}=C_{\Sigma}{ }^{\prime} \cdot p
$$

Ланка 3 коефіцієнтом передачі $\mathrm{W}_{7}$ відповідає перетворенню сили $\mathrm{F}$, що діє на п'єзоелемент, в механічне напруження $\sigma$ :

$$
W_{7}=\frac{B E h y}{R^{2}}
$$

де $\mathrm{h}$ - товщина пластини біморфного п'єзоелемента, Е - модуль пружності матеріалу пластини, у - переміщення центру пластини, що залежать від впливу сили

$$
B=\frac{4}{1-\mu} \cdot \frac{k^{2}\left(k^{2}-1\right)}{k^{4}-4 k^{2} \cdot \ln k-1} \quad k=\frac{R}{r}
$$

$\mathrm{R}, \mathrm{r}$ - радіус пластини біморфного п'єзоелемента відповідно. $\mu$ - коефіцієнт Пуассона.

Ланка $\mathrm{W}_{8}$ відповідає перетворенню механічної напруги в деформацію біморфного п'єзоелемента

$$
W_{8}=\frac{\sigma}{E}
$$

Було розроблено кілька варіантів схем, запропонованих на рис. $3[9,10]$.

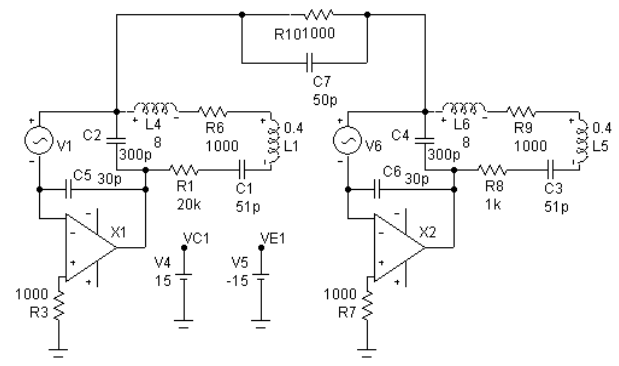

a)

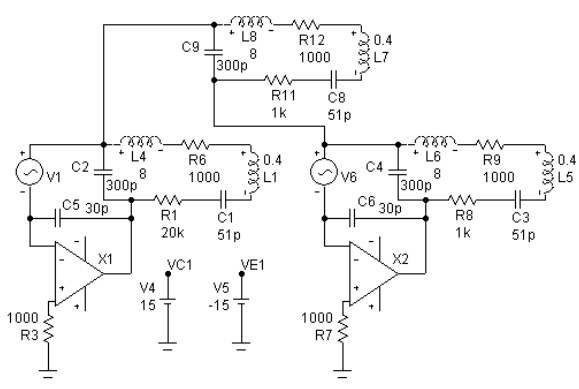

б)

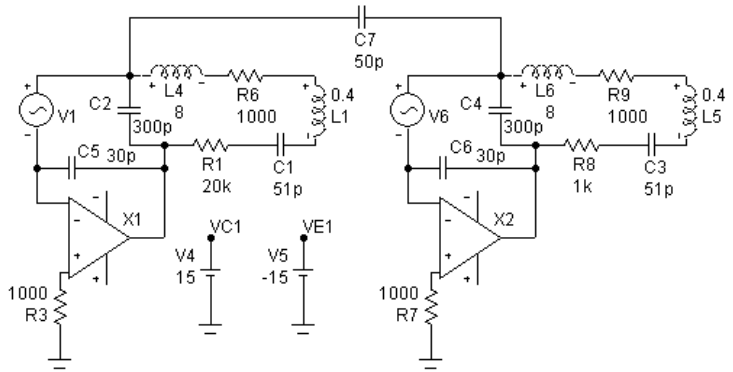

B)

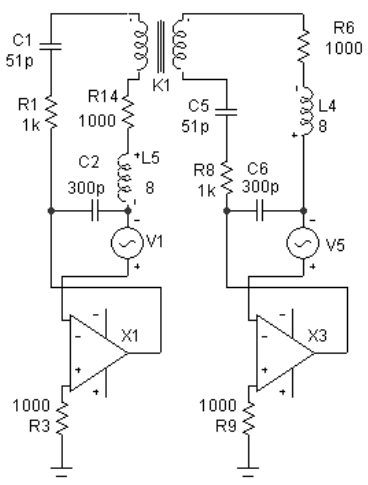

1)
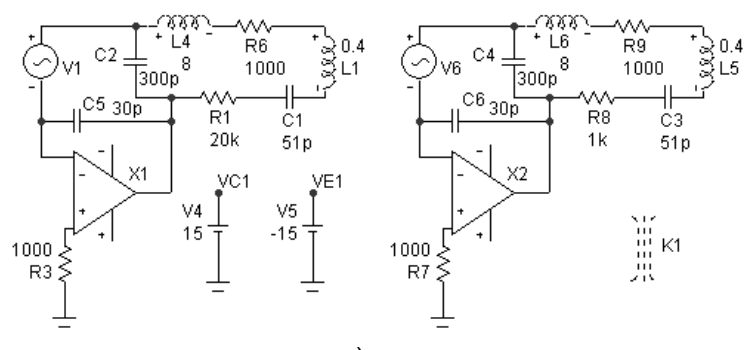

д)

Рис. 3. Пов'язані коливальні системи поліелектродних п'єзокерамічних елементів: a) зі зв'язком через RC-контур; б) зі зв'язком через RLC-контур; в) з зовнішньо-ємнісним зв'язком; г) 3 трансформаторним зв'язком; д) з взаємоіндукцією

Результати моделювання варіантів схем п'єзоперетворювачів у програмі MicroCар запропоновані в табл. 2.

Під час детального порівняння амплітудно-частотних характеристик усіх варіантів схем (табл. 2) з експериментальними результатами було встановлено, що найбільш точно процеси, які відбуваються в поліелектродних п'єзоелементах, описує схема, зображена на рис. 3 , в) зв'язок через взаємоіндукцію.

В результаті порівняння експериментальних результатів 3 теоретичними похибками схемотехнічного моделювання (для схеми рис. 3 , д) $-3 \%$. 


\section{Пов'язані коливальні системи}

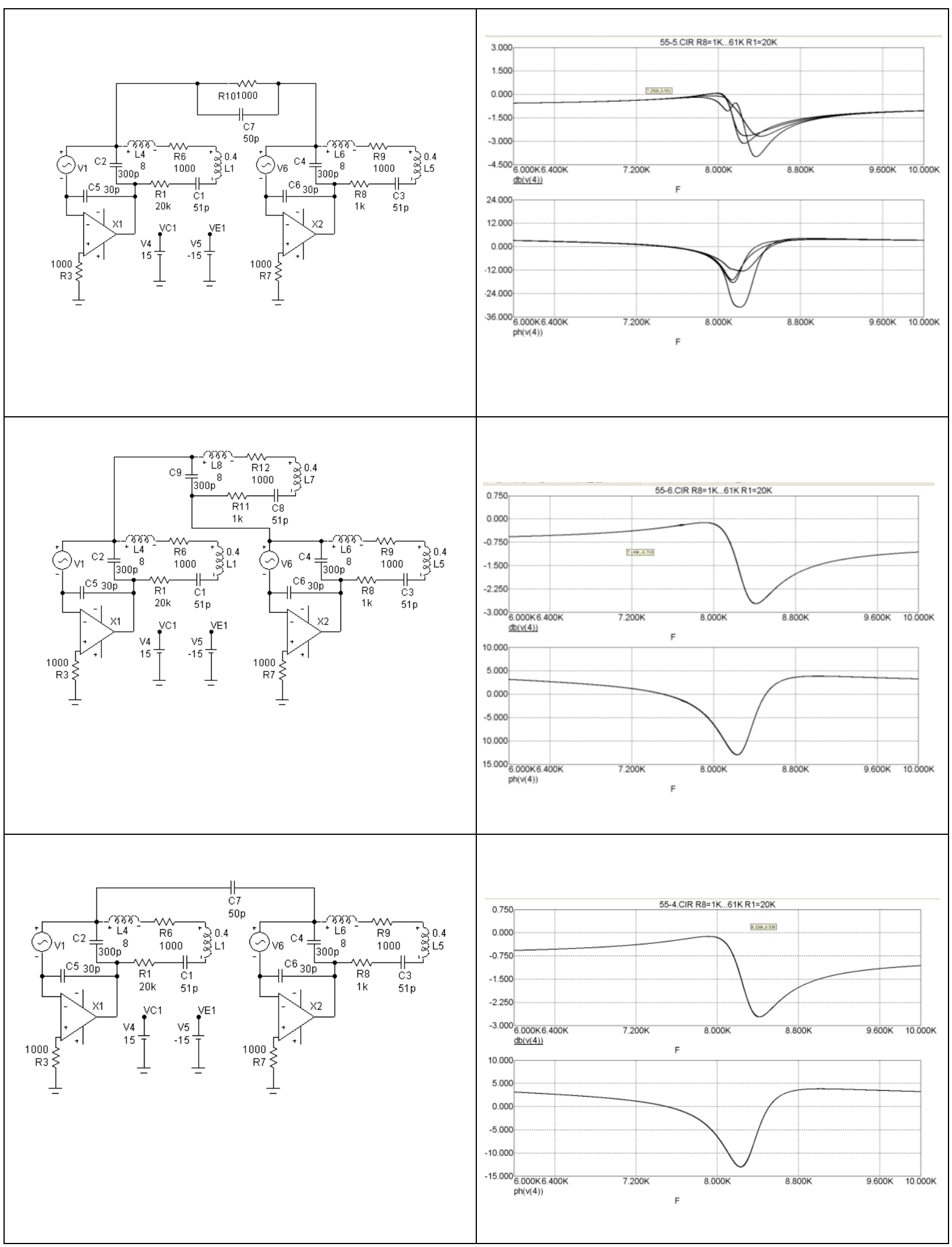




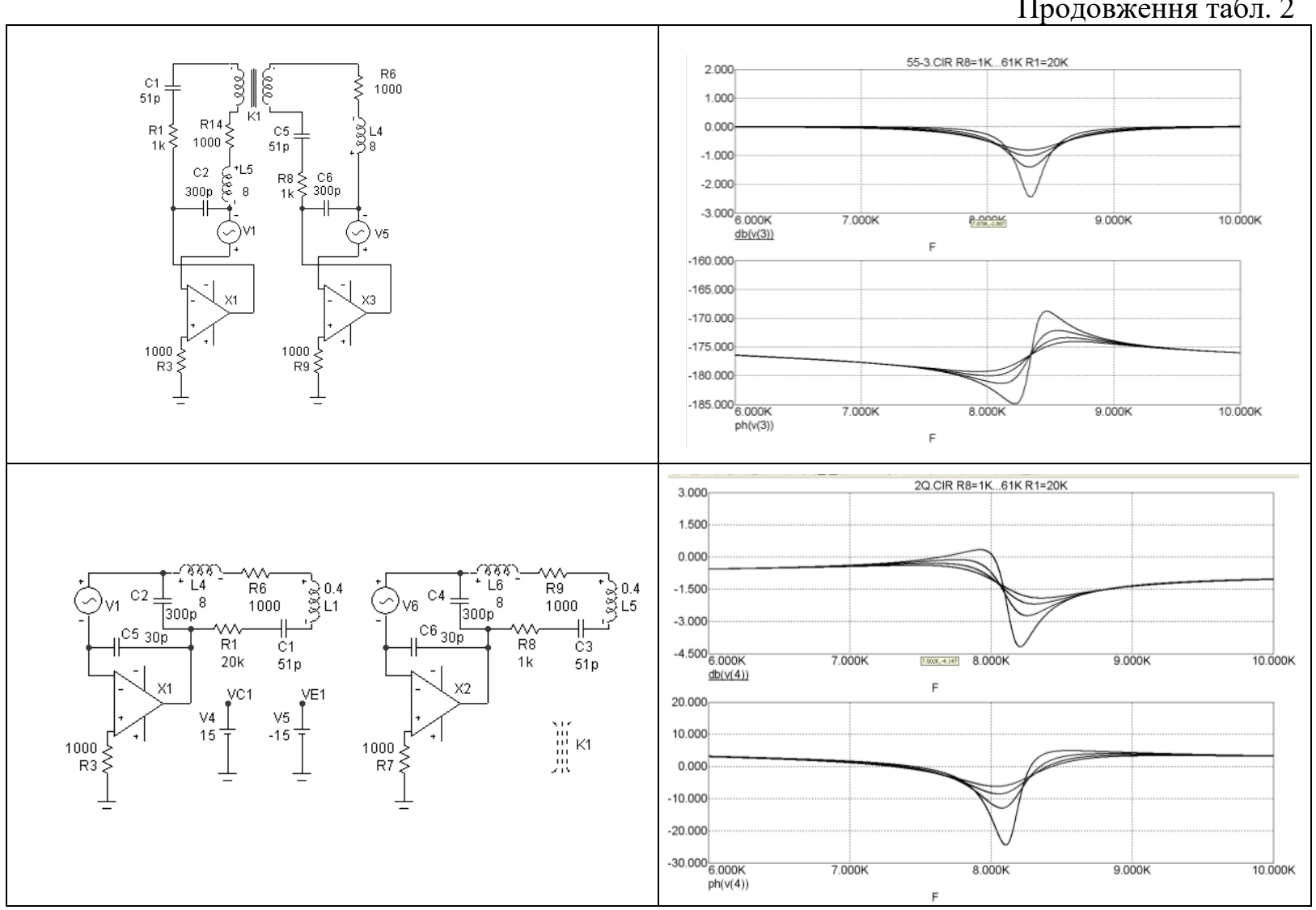

Висновок. Досліджено схемотехнічні моделі біморфних п'єзоєлементів, виявлено оптимальну електричну схему і п'єзоперетворювачі $з$ вихідним підсилювачем заряду та підсилювачем напруги в додатковому каналі зворотного зв'язку. Отримано амплітудночастотні, фазо-частотні характеристики та перехідні характеристики п'єзоперетворювачів. Отримані дані збігаються з результатами теоретичних досліджень.

\section{Список літератури}

1. Мусиенко М. П. Полиморфные пьезокерамические преобразователи давления с пространственной электромеханической отрицательной обратной связью: дис. докт. техн. наук: 05.13.05. Одесса, 2006. $172 \mathrm{c}$.

2. Шарапов В. М., Мусиенко М. П. и др. Пьезокерамические преобразователи с дополнительным каналом обратной связи. Вісник Черкаського державного технологічного університету. Серія: Технічні науки. 2004. № 3. С. 101-107.
3. Шарапов В. М., Мусиенко М. П. Определение условий повышения точности пьезопреобразователей с двумя цепями обратной святи. Вісник Черкаського державного технологічного університету. Серія: Технічні науки. 2005. № 2. С. 24-27.

4. Шарапов В. М., Мусиенко М. П. Повышение точности пьезопреобразователей с двумя цепями пространственной электромеханической отрицательной обратной святи. Вісник Черкаського державного технологічного університету. Серія: Технічні науки. 2005. № 2.

5. Шарапов В. М., Мусиенко М. П. Пьезопреобразователи с двумя цепями пространственной электромеханической отрицательной обратной святи. Вісник Черкаського державного технологічного університету. Серія: Технічні науки. 2005. № 1.

6. Шарапов В. М., Мусиенко М. П., Шарапова Е. В. Пьезокерамические преобразователи физических величин / под ред. В. М. Шарапова. Черкассы: ЧГТУ, 2005. $631 \mathrm{c}$.

7. Шарапов В. М., Мусиенко М. П., Туз В. В. Пьезоэлектрический преобразователь с 
пьезоэлементом в цепи обратной связи усилителя заряда. Вісник Черкаського дер-жавного технологічного університету. Серія: Технічні науки. 2006. № 2. C. $118-120$.

8. Шарапов В. М. Минаев И. Г., Бондаренко Ю. Ю., Кисиль Т. Ю., Мусиенко М. П., Роттэ С. В., Чудаев И Б. Пьезоэлектрические преобразователи: справ. пособие / под ред. В. М. Шарапова. Черкассы: ЧГТУ, 2004. 435 c.

9. Патент України 12410. П'єзоелектричний перетворювач механічних величин / Шарапов В. М., Мусієнко М. П., Туз В. В. МПК G01R31/02 по заявці № 200505700 від 13.06.2005, опубл. 15.02.06, Бюл. № 2.

10. Патент України 12411. П'єзоелектричний перетворювач механічних величин / Шарапов В. М., Мусієнко М. П., Туз В. В. МПК G01L 1/16 по заявці № 200505701 від 13.06.2005, опубл. 15.02.06, Бюл. №2 .

\section{References}

1. Musienko, M. P. (2006) Polymorphic piezoceramic pressure transducers with dimensional electromechanical inverse feedback. Doctor's thesis research. Odessa. 172 p. [in Russian].

2. Sharapov, V. M., Musienko, M. P. et al. (2004) Piezoceramic transducers with additional feedback path. Visnyk Cherkaskogo derzhavnogo tehnologichnogo universitetu. Seria: Tehnichni nauky, No. 3, pp. 101-107 [in Russian].

3. Sharapov, V. M., Musienko, M. P. (2005) Defining conditions for improving the accuracy of piezoelectric transducers with two feedback circuits. Visnyk Cherkaskogo derzhavnogo tehnologichnogo universitetu. Seria: Tehnichni nauky, No. 2, pp. 24-27 [in Russian].
4. Sharapov, V. M., Musienko, M. P. (2005) Improving the accuracy of piezoelectric transducers with two circuits of dimensionalelectromechanical inverse feedback. Visnyk Cherkaskogo derzhavnogo tehnologichnogo universitetu. Seria: Tehnichni nauky, No. 2 [in Russian].

5. Sharapov, V. M., Musienko, M. P. (2005) Piezoelectric transducers with two circuits of dimensional electromechanical inverse feedback. Visnyk Cherkaskogo derzhavnogo tehnologichnogo universitetu. Seria: Tehnichni nauky, No. 1 [in Russian].

6. Sharapov, V. M., Musienko, M. P., Sharapova, E. V. (2005) Piezoceramic transducers of physical quantities / Sharapov V. M. (ed.). Cherkassy: ChGTU, 631 p. [in Russian].

7. Sharapov, V. M., Musienko, M. P., Tuz, V. V. (2006) Piezoelectric transducer with piezoelement in the inverse feedback circuit of charge amplifier. Visnyk Cherkaskogo derzhavnogo tehnologichnogo universitetu. Seria: Tehnichni nauky, No. 2, pp. 118-120 [in Russian].

8. Sharapov, V. M., Minaiev, V. M., Bondarenko, Yu. Yu., Kisil, T. Y., Musienko, M. P., Rotte, S. V., Chudaieva, I. B. (2004) Piezoelectric transducers: reference book. Ed. by Sharapov V. M. Cherkassy: ChGTU, 435 p. [in Russian].

9. Patent of Ukraine 12410. Piezoelectric transducer of mechanical quantities. Sharapov, V. M., $\quad$ Musienko, M. P., Tuz, V. V. IPC G01R31/02 on application No. 200505700 dated 06.13.2005, published on 02.15.2006, Bull. No. 2 [in Ukrainian].

10. Patent of Ukraine 12411. Piezoelectric transducer of mechanical quantities. Sharapov, V. M., $\quad$ Musienko, M. P., Tuz, V. V. IPC G01L1/16 on application No. 200505701 dated 06.13.2005, published on 02.15.2006, Bull. No. 2 [in Ukrainian]. 
V. V. Tuz, Ph.D., associate professor,

e-mail: clava2005@gmail.com

T. Yu. Kisil, Ph.D., associate professor

e-mail: kisiltetyana@ukr.net

Cherkasy State Technological University

Shevchenko blvd, 460, Cherkasy, 18006, Ukraine

\section{INVESTIGATION AND SELECTION OF OPTIMIZED CIRCUIT MODEL OF BIMORPH PIEZOELECRIC ELEMENT OF DYNAMIC PRESSURE WITH DUAL-CIRCUIT INVERSE FEEDBACK}

Issues related to the selection of the optimized circuit model of a bimorph piezoelectric element of dynamic pressure with dual-circuit inverse feedback are reviewed. Characteristics of piezoelectric transducers with source charge amplifier and voltage amplifier in additional feedback path are investigated.

Key words: bimorph piezoelectric element, piezoelectric transducer, inverse feedback, temperature parameters, timing parameters, charge amplifier, voltage amplifier.

Стаття надійшла 12.03.2018.

Рецензенти: $\quad$ Г. С. Тимчик, д.т.н., професор,

В. М. Рудницький, д.т.н., професор. 